\title{
Grafting of Romanian Melons and Watermelons for Culture from South Area of Romania
}

\author{
Dorin SORA, Mădălina DOLTU*, Simona POPESCU, Daniela IORGA \\ Department of Horticultural Cultures in Protected Spaces, Research and Development Institute for \\ Processing and Marketing of Horticultural Products - Horting, Bucharest, Romania \\ *)Corresponding author, e-mail: doltu_mada@yahoo.com
}

BulletinUASVM Horticulture 73(2) / 2016

Print ISSN 1843-5254, Electronic ISSN 1843-5394

DOI:10.15835/buasvmcn-hort:12265

\begin{abstract}
The vegetable grafting is useful in Romania; it is more difficult in watermelons and melons and it is continuously developing. The research was aimed the establishing of the technological stages for seedling producing of scions (Romanian melons and watermelons) and rootstocks ( $\mathrm{F}_{1}$ hybrids of Lagenaria siceraria and Cucurbita maxima $\mathrm{x}$ C. moschata) for obtaining of grafted plant seedlings. The experience was realized out on a collection consisting from two Romanian scions, melon ('Fondant' variety) and watermelon ('Dochița' variety) obtained at Research and Development Station for Vegetable Growing Buzău and two rootstocks, bottle gourd - L. siceraria ('Emphasis' $\mathrm{F}_{1}$ ) and interspecific hybrid squash - C. maxima x C. moschata ('Cobalt' $\mathrm{F}_{1}$ ). The obtaining of scion and rootstock plants was made according to the ecological requirements of the species. The grafting was by splice. The plants had optimal diameters for splice grafting. Between scions ('Fondant' and 'Dochița') are no diference at grafting. Technological stages were established for producing grafted seedlings of Romanian melon and watermelon. The grafting was performed successfully for cucurbit plants (scions and rootstocks). These technological stages for splice grafting of Romanian melons and watermelons are recommended for cultures in the south area of Romania.
\end{abstract}

Keywords: cucurbits, grafted seedlings, Romanian scions

\section{Introduction}

The vegetable grafting is useful in Romania; it is more difficult in watermelons and melons and it is continuously developing. Bogoescu et al., 2015 highlights a better resistance of the rootstock to Meloidogyne incognita and Fusarium oxysporum attack, compared to the ungrafted cultivar. Sensivity to diseases and pest has imposes introduction grafting cultivars on resistant at rootstocks (Bogoescu et al. 2010). The grafting is an another agronomic interest for vigor and production (Tarchout et al., 2005).

\section{Aims and objectives}

The research was aimed the establishing of the technological stages for producing of Romanian melons and watermelons grafted seedlings.

\section{Materials and methods}

The experience was realized out on a collection consisting from two Romanian scions, melon ('Fondant' variety, 1000 seeds) and watermelon ('Dochița' variety, 1000 seeds) obtained at Research and Development Station for Vegetable Growing Buzău and two rootstocks, bottle gourd - L. siceraria ('Emphasis' $\mathrm{F}_{1}, 1000$ seeds) and interspecific hybrid squash - C. maxima x C. moschata ('Cobalt' $\mathrm{F}_{1}, 1000$ seeds). '

Fondant' is early variety with yellow and spherical fruit. It has weight of $1,5-3 \mathrm{~kg} /$ fruit and it is cultivated in protected spaces and field. 'Dochița' is semi-early variety with striped green and spherical fruit and average weight of $5,5 \mathrm{~kg} /$ fruit. It is cultivated in field.

The obtaining of scion and rootstock plants was made according to the ecological requirements of the species. The grafting was by splice. 


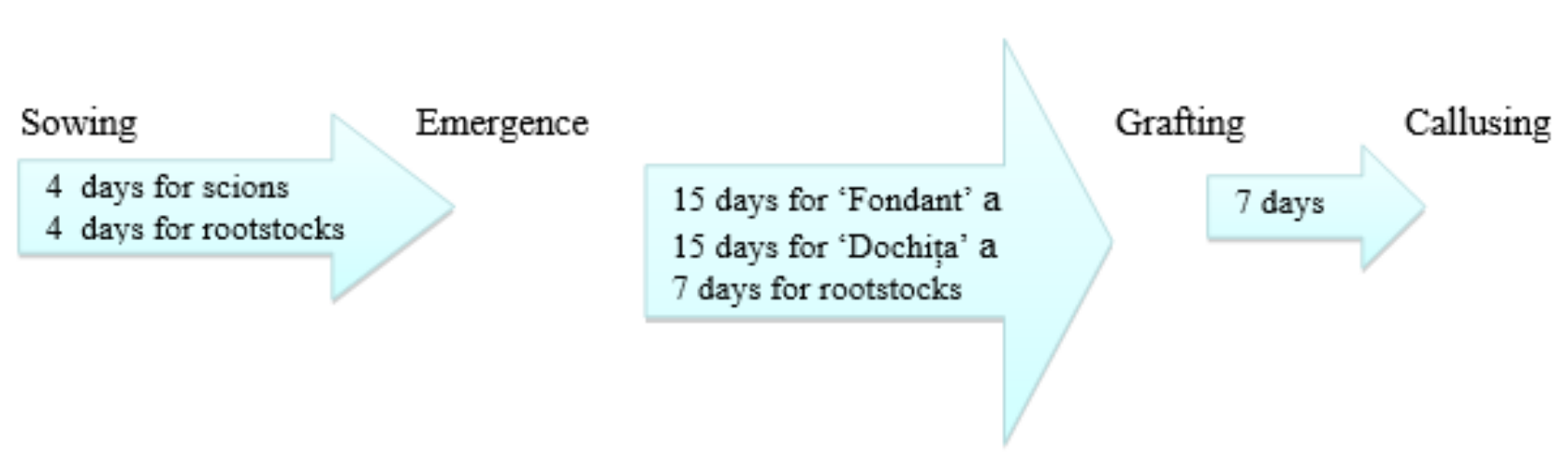

Duncan test $\mathrm{p}<0,05$

Fig. 1. Technological stages of melon and watermelon grafting

The statistical analysis was carried out by Duncan test.

\section{Results and Discussion}

Obtaining of grafted melon and watermelon seedlings implies following steps:

- sowing scion and rootstock - in alveolar trays (24 ml/cell volume) with nutritive substrate (peat ${ }_{3}$ : perlite $_{1}$ ) of grain size $0-10 \mathrm{~mm}$.

After sowing, the plants are cultivated in classic conditions for cucurbit seedlings.

- preparing for grafting - necessary materials (clips, razor blades, disinfectants for hands),

- grafting - manual cutting, method by splice grafting, rootstock with one-cotyledon and without root. The plants had optimal diameters (2-2,5 mm).

Bogoescu et al., 2009 say that the optimum diameter for rootstock and scion is $2 \mathrm{~mm}$.

- forming of callus - in polyethylen tunnel with specific microclimate conditions (temperature of $23-25^{\circ} \mathrm{C}$ and relative air humidity of 98$100 \%$ ), closed tunnel for 4 days and ventilated tunnel from $5^{\text {th }}$ day,

- transferring of grafted seedlings from the space for callus forming in the growing greenhouse.

The technological stages for producing grafted seedlings of Romanian melon and watermelon were established in greenhouse from the Horting Institute Bucharest (Fig. 1).

Between scions ('Fondant' and 'Dochița') are no diference, splice grafting is to 15 days from emergence of plants - Duncan test. In speciality literature are similar results about some watermelons from import. Doltu et al., 2013 say that the grafting was realized after 5-6 days from emergence of rootstocks ('TZ148' and 'Shintoza') and 15-16 days from emergence of scion ('Santa Vittoria').

The grafting was performed successfully (93\% grafted plants/scion cultivar).

\section{Conclusion}

Splice grafting is to 15 days from emergence of plants at Romanian melon and watermelon scions. The grafting was performed successfully for cucurbit plants (scions and rootstocks), 93\% grafted plants/scion cultivar. These technological stages for splice grafting of Romanian melons and watermelons are recommended for cultures in the south area of Romania.

\section{REFERENCES}

1. Bogoescu M, Doltu M, Sora D, Mohora A, Iordache B (2009). Results on establishing the technology for obtaining the watermelons grafted seedlings. Bulletin UASVM, Horticulture Cluj-Napoca vol. 66(1) :397-403.

2. Bogoescu M, Doltu M, Iordache B, Tănasa N, Sora D, Mohora A (2010). Grafting Watermelons Crop - Non Chemical Methyl Bromide Alternative in Romanian Horticulture. Bulletin UASVM Horticulture Cluj-Napoca 67(1):224-229.

3. Bogoescu M, Mohora A, Sora D (2015). Altoirea - metodă biologică de optimizare a tehnologiilor de cultură a pepenilor verzi în condițiile accentuării factorilor de stres biotici și abiotici. HORTUS Revistă a horticultorilor și viticultorilor. Ed. ARTPRINT. 14:215-220.

4. Doltu M, Bogoescu M, Sora D (2013). Technological aspects concerning establishment the phenotypic compatibility rootstock/scion to watermelons. "Lucrări ştiințifice" USAMV Iași, seria Horticultură, 56(2):161-166.

5. Tarchout N, Boughalleb N, El Mbaraki A (2005). Agronomic evaluation of nine cucurbit rootstocks and watermelon grafted (Citrullus lanatus L.). Revue de l'INAT 20:125-140. 